\title{
COMPARATIVE SEM AND EDX ANALYSIS OF SURFACE COATINGS CREATED ON NIOBIUM AND TITANIUM ALLOYS AFTER PLASMA ELECTROLYTIC OXIDATION (PEO)
}

\author{
Krzysztof Rokosz, Tadeusz, Hryniewicz
}

Original scientific paper

In the paper, the SEM and EDS study results of the surface coatings formed on the niobium and titanium alloys (TNZ, NiTi, Ti6Al4V) after the Plasma Electrolytic Oxidation (PEO), also known as Micro Arc Oxidation (MAO), are described. For the experiment of the PEO treatment, a non-conventional electrolyte, based on the concentrated orthophosphoric acid, was used. Copper-enriched surface coatings on the biomaterials after the PEO were obtained and studied. General surface characteristics, regarding the metallic biomaterials after the PEO treatment, with the significant differences of the results, have been displayed and statistically developed.

Keywords: Plasma Electrolytic Oxidation (PEO); Micro Arc Oxidation (MAO); SEM; EDS Analysis; Niobium; TNZ (Ti-Nb-Zr); NiTi; Ti6Al4V

\section{Usporedna SEM i EDX analiza površinskih slojeva nastalih na legurama niobija i titanija nakon plasma elektrolitičke oksidacije} (PEO)

Izvorni znanstveni članak U radu su opisani rezultati SEM i EDS analize površinskih slojeva nastalih na legurama niobija i titanija (TNZ, NiTi, Ti6Al4V) nakon plazma elektrolitičke oksidacije (PEO), poznate i kao mikro lučna oksidacija (Micro Arc Oxidation - MAO). Za eksperiment PEO postupka upotrebljen je nekonvencionalni elektrolit, temeljen na koncentriranoj ortofosfornoj kiselini. Nakon PEO dobiveni su i proučavani bakrom obogaćeni površinski slojevi na biomaterijalu. Prikazane su i statistički obrađene opće značajke površine u odnosu na kovinske biomaterijale nakon PEO postupka, uz značajne razlike u rezultatima.

Ključne riječi: plazma elektrolitička oksidacija (PEO), mikro lučna oksidacija (MAO), SEM, EDS analiza, niobij, TNZ (Ti-Nb-Zr); NiTi; Ti6Al4V

\section{Introduction}

Metals such as titanium, niobium, tantalum, zirconium $[1 \div 6]$ and their alloys $[7 \div 12]$ as well as stainless steels $[13 \div 26]$ are used in medicine as biomaterials. However, after the medical device shape formation, they have to be processed most often by mechanical and electrochemical treatments. As the first electrochemical process after the mechanical operations most often the standard electrochemical polishing (EP) $[14,27]$ or magnetoelectropolishing (MEP) [28-30] and/or high-current density electropolishing (HDEP) [17, $23 \div 25$ ] processes are used. Such prepared metal surface may undergo other treatments, such as the plasma electrolytic oxidation (PEO) operation known also as the

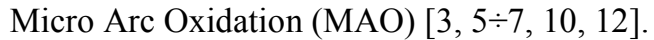

The idea of preparing layers and/or coatings on biomaterials such as titanium and its alloys within copper ions by PEO has been supported by the necessities of industry interested in effective biomaterials production. On the basis of the MATERION-GmbH company's experience and needs [31], which employs multilayered coatings prepared on biomaterials, obtained specifically by PVD and CVD methods, our team began to perform a lot of experiments based on electrochemical processes to reach this goal. That way we managed to obtain about ten-micrometer thick layer of phosphates enriched with the copper ions throughout the whole volume of the coating. There are many papers describing antibacterial effect of silver $[32 \div 35]$ and copper $[36 \div 38]$ ions inserted in the porous coatings. However, there are no reported results related to the $\mathrm{PEO}$ layers/coatings formed in an electrolyte containing concentrated phosphoric acid with nitrate salts of copper and/or silver. The problem is of high importance and the solution proposed by the Authors of this work is new and original. In this paper the Authors would like to present the preliminary study to develop the achievement and prove the results are unique and of great significance, which will be the basis for further research.

The PEO method allows to create a relatively thick surface coating with the thickness of about ten micrometers. Metals and alloys consisting of titanium, niobium, tantalum, zirconium are very often used in biomedicine applications because of the mechanical and corrosion properties as well as their very good biocompatibility. During the PEO treatment of the metals and alloys the porous surface coating is formed, being the transient layer between the tissue and pure biomaterial matrix after implantation.

In the paper, the Authors present the results of the PEO treatment performed on a pure niobium and three titanium alloys (TNZ, NiTi, Ti6Al4V) at the voltage of $450 \mathrm{~V}$ in the electrolyte consisting of concentrated phosphoric acid within copper nitrate. There are no publications available on the studies performed in that electrolyte as yet. Copper nitrate introduced into the phosphoric acid electrolyte has allowed for the introduction of copper ions into the porous coating created on the studied biomaterials.

\section{Method}

\subsection{Material}

The niobium and titanium alloys such as TNZ (Ti 74, $\mathrm{Nb} 20, \mathrm{Zr} 6$ wt\%), NiTi(Ni 50, Ti 50 wt\%), Ti6Al4V (Ti 90, Al 6, V $4 \mathrm{wt} \%$ ) samples were used for the study. For the PEO experiments, some sets of niobium and titanium alloys samples of dimensions $30 \times 20 \times 1 \mathrm{~mm}$, were prepared. Prior to the PEO treatment, all the samples were mechanically polished (MP) using SiC abrasive 
paper of 600 grit size, then cleaned with acetone and dried in the air.

\subsection{Set up}

The Plasma Electrolytic Oxidation (PEO) operations were performed at the voltage of $450 \mathrm{~V}$. The treatments were carried out in the electrolyte of initial temperature of $25^{\circ} \mathrm{C}$ for three minutes. For the studies, the electrolyte containing $500 \mathrm{ml}$ of concentrated orthophosphoric acid within $300 \mathrm{~g}$ of copper nitrate, was used. The electrolytic cell made of glass was used, containing up to $500 \mathrm{~cm}^{3}$ of the electrolyte solution.

\subsection{Apparatus and procedures}

All the SEM and EDX studies were carried out by means of a scanning electron microscope Quanta 250 FEI with low vacuum and ESEM mode and a field emission cathode. The Energy-dispersive X-ray spectroscopy (EDX) system is a Noran System Six with nitrogen-free Silicon Drift Detector. The EDS data, by statistical methods using STATISTICA software [39], were processed. In this work, the uncertainty type A derived from the measurement results' variances [40, 41], not from the device errors (uncertainty type B), was analysed.

(a)

(b)

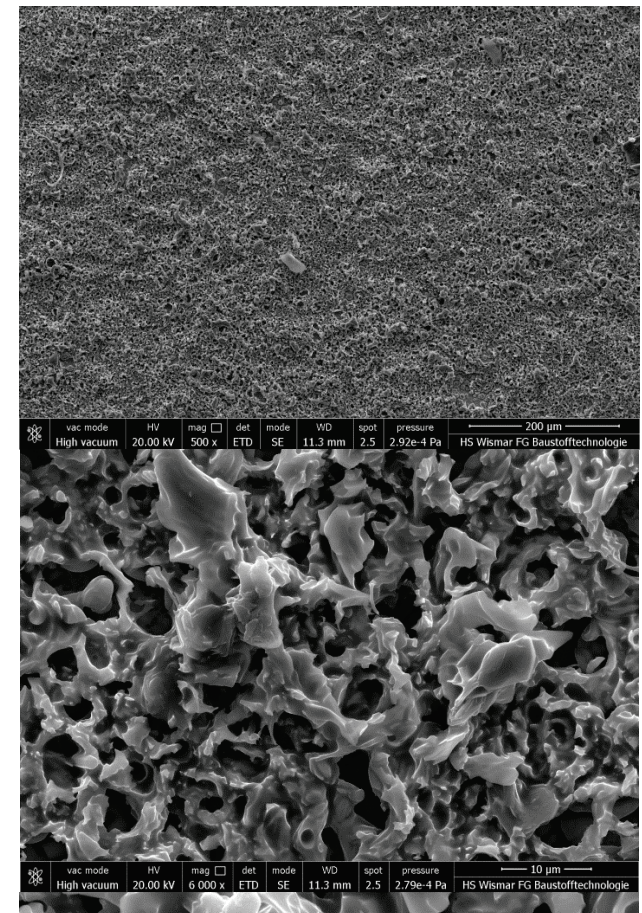

(c)

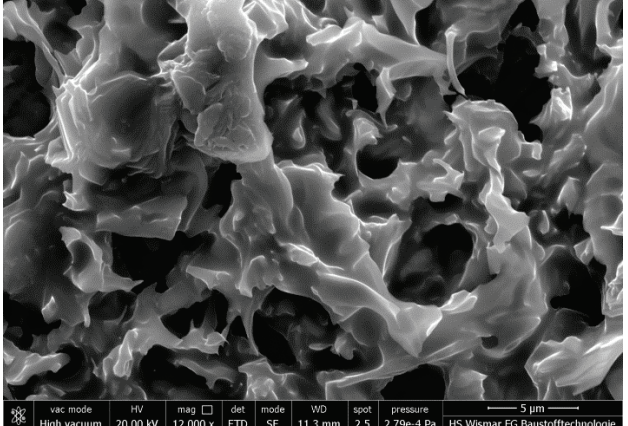

Figure 1 SEM of Niobium surface after PEO at $450 \mathrm{~V}$ in mixture containing $500 \mathrm{ml} \mathrm{H}_{3} \mathrm{PO}_{4}$ within $300 \mathrm{~g} \mathrm{Cu}\left(\mathrm{NO}_{3}\right)_{2}$ (magnifications: (a) 500 times; (b) 6000 times; (c) 12000 times)

\section{Results and analysis}

In Figs. 1a, $1 \mathrm{~b}$ and $1 \mathrm{c}$, there are shown the SEM images of Niobium surface coating after the Plasma Electrolytic Oxidation at the voltage of $450 \mathrm{~V}$, with the magnifications 500, 6000, 12000 times, respectively. The obtained surfaces are porous, that is best visible in Fig. 1c. On the basis of EDX result, presented in Fig. 2 and Tab. 1, it can be concluded, that in the porous surface coating there is a lot of phosphorus and oxygen with a lower amount of copper.

The majority of the niobium signal is most likely derived from the matrix. In view of presenting the reliable factor describing the surface coating containing mainly phosphorus and copper, the Authors propose a new coefficient, i.e. the copper-to-phosphorus ratio $(\mathrm{Cu} / \mathrm{P})$. On the basis of the descriptive statistics it can be assumed that the $\mathrm{Cu} / \mathrm{P}$ ratio for niobium sample oxidized in the concentrated phosphoric acid within copper nitrate at 450 $\mathrm{V}$ is equal to $0,22 \pm 0,02$ with the median and range of 0,23 and 0,05 , respectively. Additionally, the other two ratios, i.e. phosphorus-to-matrix and copper-to-matrix were found. As the matrix, the sum of the percentages by weight of the elements contained in the metal or alloy without any treatment, was assumed. In this case, it is only niobium. Following that way it should be noted that the phosphorus-to-matrix (niobium) ratio is equal to $0,54 \pm 0,02$ with the median and range of 0,55 and 0,06 , respectively. On the other hand, the copper-to-matrix (niobium) ratio is $0,12 \pm 0,01$ with the median and range of 0,12 and 0,02 , respectively.

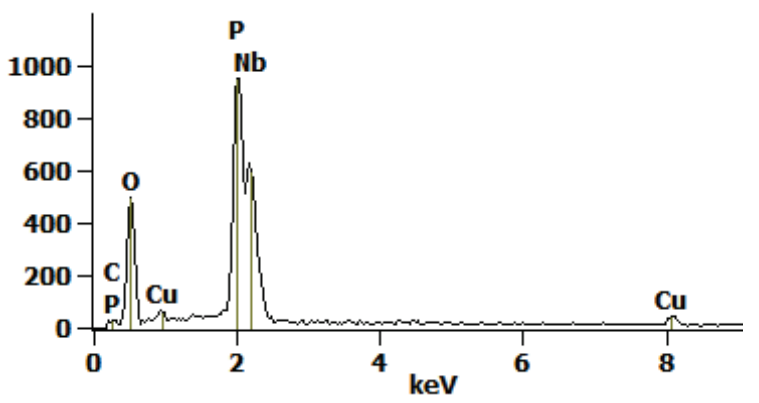

Figure 2 EDS result of Niobium surface after PEO at $450 \mathrm{~V}$ in mixture containing $500 \mathrm{ml} \mathrm{H}_{3} \mathrm{PO}_{4}$ within $300 \mathrm{~g} \mathrm{Cu}\left(\mathrm{NO}_{3}\right)_{2}$

Table 1 Quantitative results of weight and atomic concentration of selected elements on the basis of EDS presented in Fig. 2 (Niobium)

\begin{tabular}{|c|c|c|c|c|}
\hline $\begin{array}{c}\text { Element } \\
\text { lines }\end{array}$ & $\mathrm{wt} \%$ & $\begin{array}{c}\text { Error } \\
\mathrm{wt} \%\end{array}$ & $\mathrm{at} \%$ & $\begin{array}{c}\text { Error } \\
\mathrm{at} \%\end{array}$ \\
\hline $\mathrm{O} \mathrm{K}$ & 42,7 & - & 72,4 & $\pm 3,6$ \\
\hline $\mathrm{P} \mathrm{K}$ & 16,6 & $\pm 0,4$ & 14,6 & $\pm 0,7$ \\
\hline $\mathrm{Fe} \mathrm{K}$ & 2,5 & $\pm 0,5$ & 1,2 & $\pm 0,5$ \\
\hline $\mathrm{Cu} \mathrm{K}$ & 4,1 & $\pm 0,5$ & 1,8 & $\pm 0,4$ \\
\hline $\mathrm{Nb} \mathrm{L}$ & 34,1 & $\pm 1,1$ & 10,0 & $\pm 0,6$ \\
\hline
\end{tabular}

In Figs. 3a, 3b and 3c, there are shown the SEM images of Titanium-Niobium-Zirconium alloy (TNZ) surface coating after the Plasma Electrolytic Oxidation at the voltage of $450 \mathrm{~V}$, with the magnifications 500, 6000, 12000 times, respectively. The surface, alike in the case of niobium, is porous but the structure of this porous coating is different (Figs. 3b and 3c) from that obtained on the niobium (compare Figs. $1 \mathrm{~b}$ and 1c). In Fig. 4 and Tab. 2, the EDX results of the PEO coating formed on 
TZN, are shown. The highest signals from niobium, zirconium, phosphorus and oxygen were detected. The titanium and copper peaks were the smallest ones, but clear. The $\mathrm{Cu} / \mathrm{P}$ ratio for the Titanium-NiobiumZirconium alloy (TNZ) treated by the PEO is equal to $0,17 \pm 0,02$ with the median and range of 0,17 and 0,07 , respectively. In this case, the sum of the percentages by weight of titanium, niobium and zirconium (TNZ) has been assumed as related to the matrix. The phosphorus-tomatrix (TNZ) ratio is equal to $0,69 \pm 0,07$ with the median and range of 0,69 and 0,22 , respectively. Herewith, the copper-to-matrix (TNZ) ratio is equal to $0,12 \pm 0,01$, with the median and range of 0,13 and 0,05 , respectively.

(a)

(b)

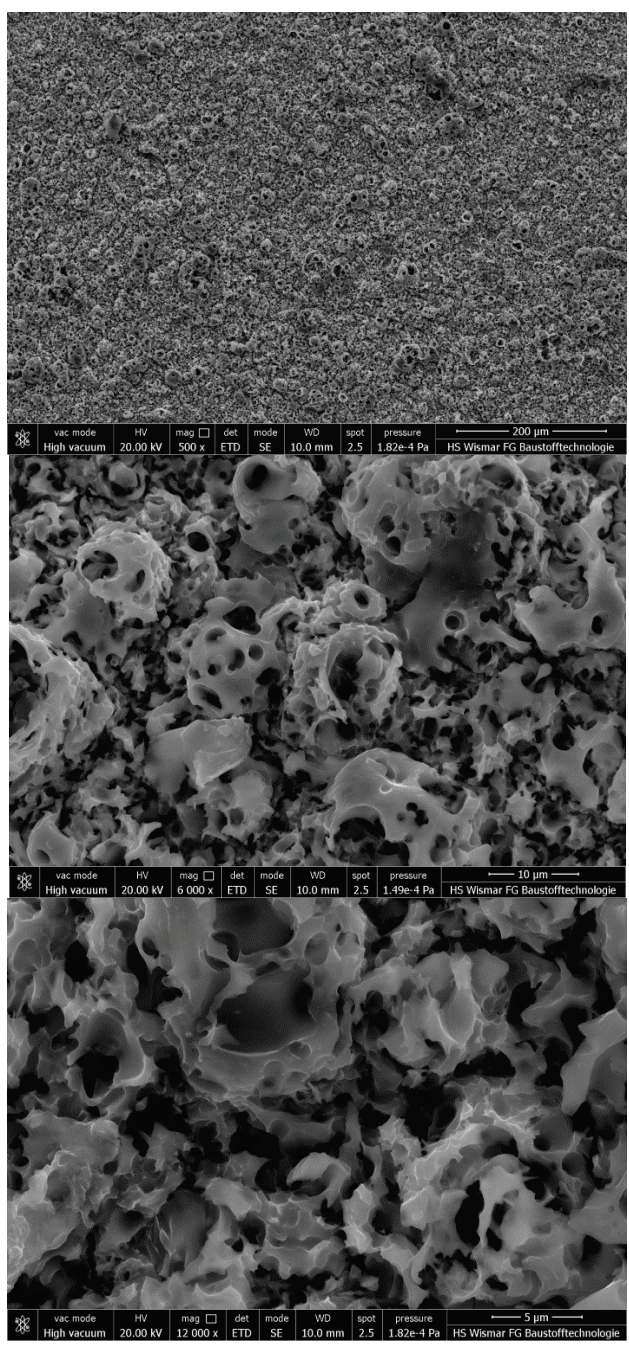

Figure $3 \mathrm{SEM}$ of TNZ surface after PEO at $450 \mathrm{~V}$ in mixture containing $500 \mathrm{ml} \mathrm{H}_{3} \mathrm{PO}_{4}$ within $300 \mathrm{~g} \mathrm{Cu}\left(\mathrm{NO}_{3}\right)_{2}$ (magnifications: (a) 500 times; (b) 6000 times; (c) 12000 times)

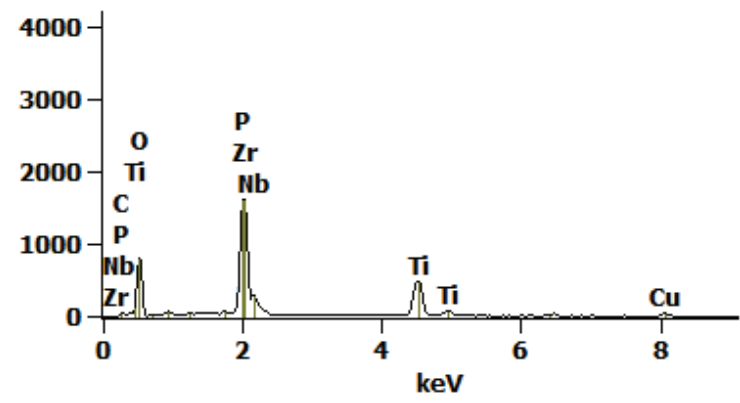

Figure 4 SEM of TNZ surface after PEO at $450 \mathrm{~V}$ in mixture containing $500 \mathrm{ml} \mathrm{H}_{3} \mathrm{PO}_{4}$ within $300 \mathrm{~g} \mathrm{Cu}\left(\mathrm{NO}_{3}\right)_{2}$ (magnifications: (a) 500 times; (b) 6000 times; (c) 12000 times)
Table 2 Quantitative results of weight and atomic concentration of selected elements on the basis of EDS presented in Fig. 4 (TNZ alloy)

\begin{tabular}{|c|c|c|c|c|}
\hline $\begin{array}{c}\text { Element } \\
\text { lines }\end{array}$ & $\mathrm{wt} \%$ & $\begin{array}{c}\text { Error } \\
\mathrm{wt} \%\end{array}$ & $\mathrm{at} \%$ & $\begin{array}{c}\text { Error } \\
\mathrm{at} \%\end{array}$ \\
\hline $\mathrm{O} \mathrm{K}$ & 48,0 & - & 72,1 & $\pm 2,3$ \\
\hline $\mathrm{P} \mathrm{K}$ & 19,3 & $\pm 0,4$ & 14,9 & $\pm 0,6$ \\
\hline $\mathrm{Ti} \mathrm{K}$ & 17,5 & $\pm 0,3$ & 8,7 & $\pm 0,3$ \\
\hline $\mathrm{Cu} \mathrm{K}$ & 3,6 & $\pm 0,3$ & 1,3 & $\pm 0,3$ \\
\hline $\mathrm{Zr} \mathrm{L}$ & 4,5 & $\pm 0,9$ & 1,2 & $\pm 0,5$ \\
\hline $\mathrm{Nb} \mathrm{L}$ & 7,1 & $\pm 0,5$ & 1,8 & $\pm 0,2$ \\
\hline
\end{tabular}

(a)

(b)

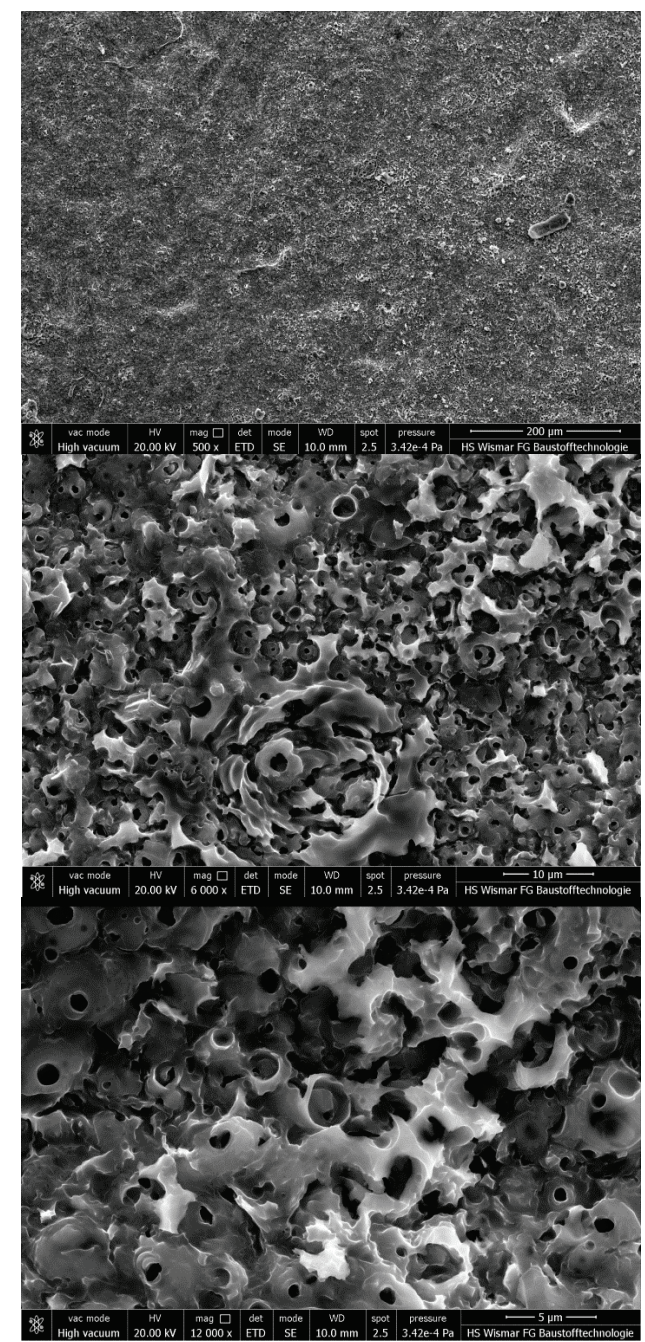

Figure 5 SEM of NiTi alloy surface after PEO at $450 \mathrm{~V}$ in mixture containing $500 \mathrm{ml} \mathrm{H}_{3} \mathrm{PO}_{4}$ within $300 \mathrm{~g} \mathrm{Cu}\left(\mathrm{NO}_{3}\right)_{2}$ (magnifications: (a) 500 times; (b) 6000 times; (c) 12000 times)

In Figs. 5a, 5b and 5c, the SEM images of the NickelTitanium alloy (NiTi) surface coating are presented after the Plasma Electrolytic Oxidation at the voltage of $450 \mathrm{~V}$; here the magnifications are 500, 6000, 12000 times, respectively. Similar to the previous cases, the obtained surface is porous, but with a different structure (Figs. 5b and $5 \mathrm{c}$ ) than that obtained for Niobium (see Fig. 1b,c) and TNZ (Figs. 3b and 3c). In Fig. 6 and Tab. 3, the EDX results of the PEO coating formed on NiTi, are presented. The $\mathrm{Cu} / \mathrm{P}$ ratio for the Nickel-Titanium alloy (NiTi) oxidized by the PEO is equal to $0,17 \pm 0,02$ with the median and range of 0,18 and 0,08 , respectively. In this case, the sum of the percentages by weight of nickel and titanium (NiTi) was adopted as related to the matrix. The phosphorus-to-matrix (NiTi) ratio is equal to $0,64 \pm 0,04$ with the median and range of 0,62 and 0,11 , respectively. 
Hereafter, the copper-to-matrix (NiTi) ratio is $0,11 \pm 0,01$ with the median and range of 0,11 and 0,04 , respectively.

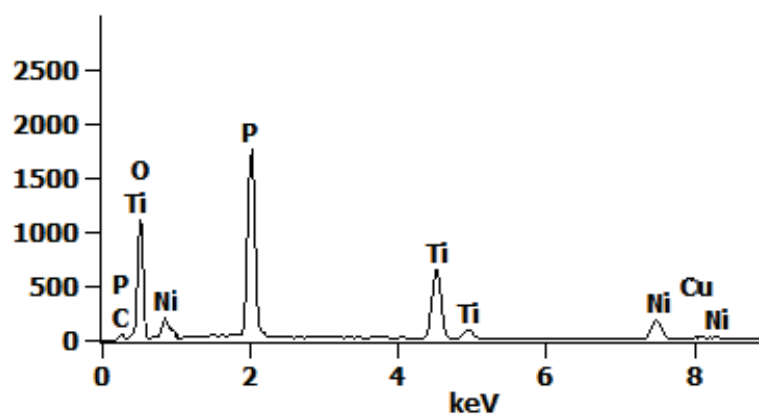

Figure 6 EDS result of NiTi alloy surface after PEO at $450 \mathrm{~V}$ in mixture containing $500 \mathrm{ml} \mathrm{H}_{3} \mathrm{PO}_{4}$ within $300 \mathrm{~g} \mathrm{Cu}\left(\mathrm{NO}_{3}\right)_{2}$

Table 3 Quantitative results of weight and atomic concentration of selected elements on the basis of EDS presented in Fig. 6 (NiTi)

\begin{tabular}{|c|c|c|c|c|}
\hline $\begin{array}{c}\text { Element } \\
\text { lines }\end{array}$ & $\mathrm{wt} \%$ & $\begin{array}{c}\text { Error } \\
\mathrm{wt} \%\end{array}$ & $\mathrm{at} \%$ & $\begin{array}{c}\text { Error } \\
\mathrm{at} \%\end{array}$ \\
\hline $\mathrm{O} \mathrm{K}$ & 46,2 & - & 69,5 & $\pm 2,0$ \\
\hline $\mathrm{P} \mathrm{K}$ & 19,1 & $\pm 0,2$ & 14,8 & $\pm 0,3$ \\
\hline $\mathrm{Ti} \mathrm{K}$ & 17,6 & $\pm 0,3$ & 8,8 & $\pm 0,3$ \\
\hline $\mathrm{Ni} \mathrm{K}$ & 13,8 & $\pm 0,6$ & 5,7 & $\pm 0,4$ \\
\hline $\mathrm{Cu} \mathrm{K}$ & 3,3 & $\pm 0,3$ & 1,2 & $\pm 0,2$ \\
\hline
\end{tabular}

(a)

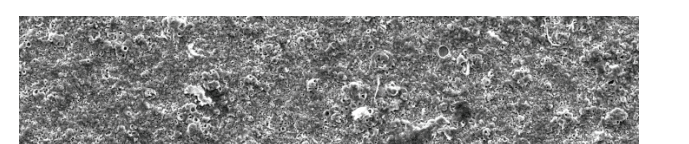

(b)

(c)

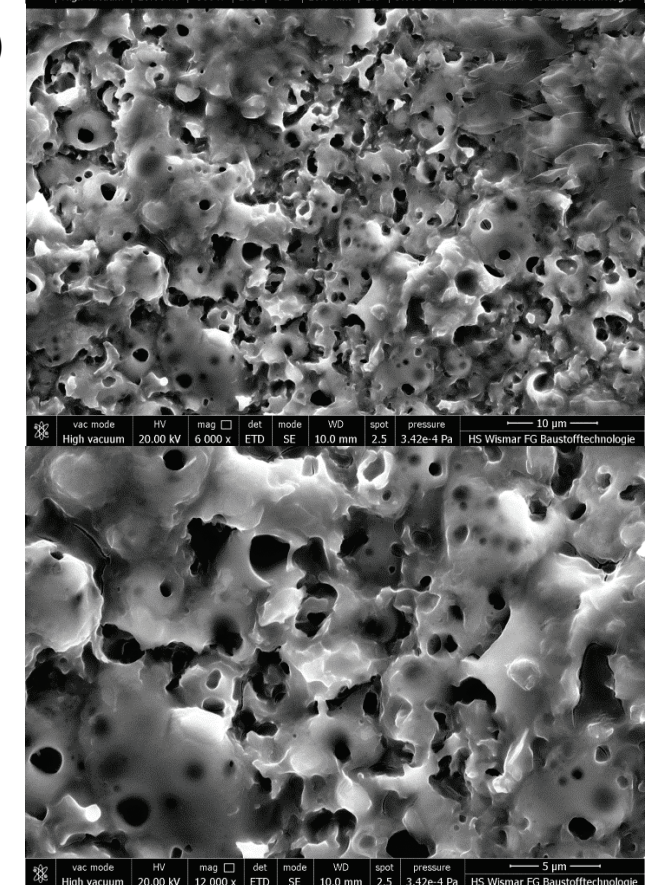

Figure $7 \mathrm{SEM}$ of Ti6Al4V alloy surface after PEO at $450 \mathrm{~V}$ in mixture containing $500 \mathrm{ml} \mathrm{H}_{3} \mathrm{PO}_{4}$ within $300 \mathrm{~g} \mathrm{Cu}\left(\mathrm{NO}_{3}\right)_{2}$ (magnifications: (a) 500 times; (b) 6000 times; (c) 12000 times)
In Figs. $7 \mathrm{a}, 7 \mathrm{~b}$, and $7 \mathrm{c}$, the SEM images of the Titanium-Aluminium-Vanadium alloy (Ti6Al4V) surface coating after the Plasma Electrolytic Oxidation at the voltage of $450 \mathrm{~V}$, have been displayed with the magnifications of 500,6000, 12000 times, respectively. Similar to the other discussed cases, the obtained surface is porous, but with a different characteristic structure (Figs. 7b and 7c) than those obtained on Niobium (Figs. $1 \mathrm{~b}$ and $1 \mathrm{c}$ ) and TNZ (Figs. 3b and 3c) and NiTi (Figs. 5b and $5 \mathrm{c}$ ). In Fig. 8 and Tab. 4, the EDX results of the PEO coating formed on Ti6Al4V, are given. The $\mathrm{Cu} / \mathrm{P}$ ratio of the Titanium-Aluminium-Vanadium (Ti6Al4V) alloy, oxidized by the PEO is equal to $022 \pm 0,03$ with the median and range of 0,22 and 0,08 , respectively. In this case, as a matrix is understood the sum of the percentages by weight of titanium, aluminium and vanadium (Ti6Al4V). The phosphorus-to-matrix (Ti6Al4V) ratio is equal to $0,83 \pm 0,06$ with the median and range of 0,81 and 0,19 , respectively. Herewith, the copper-to-matrix (Ti6Al4V) ratio is $0,18 \pm 0,02$ with the median and range of 0,18 and 0,07 , respectively.

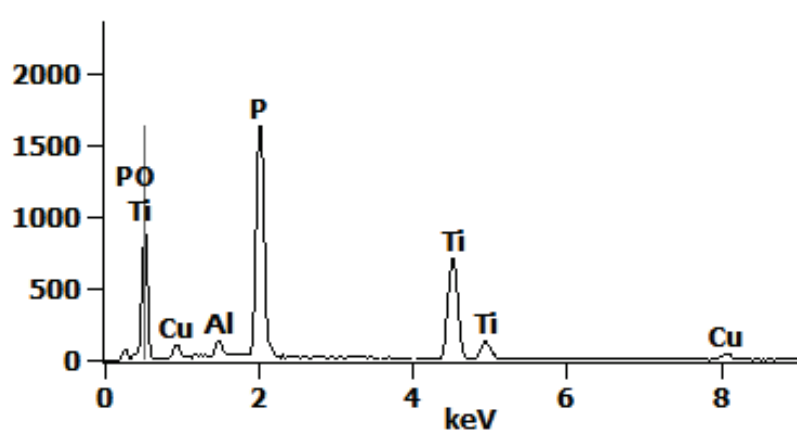

Figure 8 EDS result of Ti6Al4V alloy surface after PEO at $450 \mathrm{~V}$ in mixture containing $500 \mathrm{ml} \mathrm{H}_{3} \mathrm{PO}_{4}$ within $300 \mathrm{~g} \mathrm{Cu}\left(\mathrm{NO}_{3}\right)_{2}$

Table 4 Quantitative results of weight and atomic concentration of selected elements on the basis of EDS presented in Fig. 8 (Ti6Al4V)

\begin{tabular}{|c|c|c|c|c|}
\hline $\begin{array}{c}\text { Element } \\
\text { lines }\end{array}$ & $\mathrm{wt} \%$ & $\begin{array}{c}\text { Error } \\
\mathrm{wt} \%\end{array}$ & $\mathrm{at} \%$ & $\begin{array}{c}\text { Error } \\
\mathrm{at} \%\end{array}$ \\
\hline $\mathrm{O} \mathrm{K}$ & 51,4 & - & 72,0 & $\pm 2,1$ \\
\hline $\mathrm{Al} \mathrm{K}$ & 1,2 & $\pm 0,1$ & 1,0 & $\pm 0,1$ \\
\hline $\mathrm{P} \mathrm{K}$ & 20,5 & $\pm 0,2$ & 14,8 & $\pm 0,3$ \\
\hline $\mathrm{Ti} \mathrm{K}$ & 23 & $\pm 0,3$ & 10,8 & $\pm 0,3$ \\
\hline $\mathrm{Cu} \mathrm{K}$ & 3,9 & $\pm 0,5$ & 1,4 & $\pm 0,4$ \\
\hline
\end{tabular}

In Figs. 9 through 11, the whisker plots of $\mathrm{Cu} / \mathrm{P}$, $\mathrm{P} /$ Matrix and $\mathrm{Cu} /$ Matrix ratios are given. On the basis of these results it may be concluded that in the surface coatings formed on pure niobium and on Ti6Al4V alloy there is over 4,5 times more phosphorus than copper (by weight). In the case of the TNZ and NiTi alloys, in the surface coatings the amount of phosphorus is about six times higher than that of copper (Fig. 9). In order to explain this phenomenon, the additional analyses were carried out (see Figs. 10 and 11). Knowing that the PEO coating is composed mainly of phosphorus compounds (generally phosphates), the thickness of the surface coating may be predicted. In the case of pure niobium, the signals both of phosphorus and copper are weak relative to the signal coming from the matrix (niobium). That way one may state that the obtained PEO coating most likely is relatively thin. Although the copper-to- phosphorus ratios for Niobium and Ti6Al4V are almost the same, on the basis of the data presented in Figs. 10 and 11 it may be 
concluded that the PEO coating formed on Ti6Al4V is thicker than that one formed on the pure niobium. Additionally, regarding the amount of copper, it has to be pointed out that most likely the PEO coating of Ti6Al4V alloy is more copper-enriched than that one formed on Niobium.

In the case of TNZ and NiTi titanium alloys, which revealed also almost the same copper-to-phosphorus ratios, i.e. 0,17, it should be noted that the other two $\mathrm{Cu}$ /Matrix and $\mathrm{P} /$ Matrix ratios are also similar. For the TNZ, the PEO coating most likely is thicker and more copper-enriched than that one formed on NiTi.

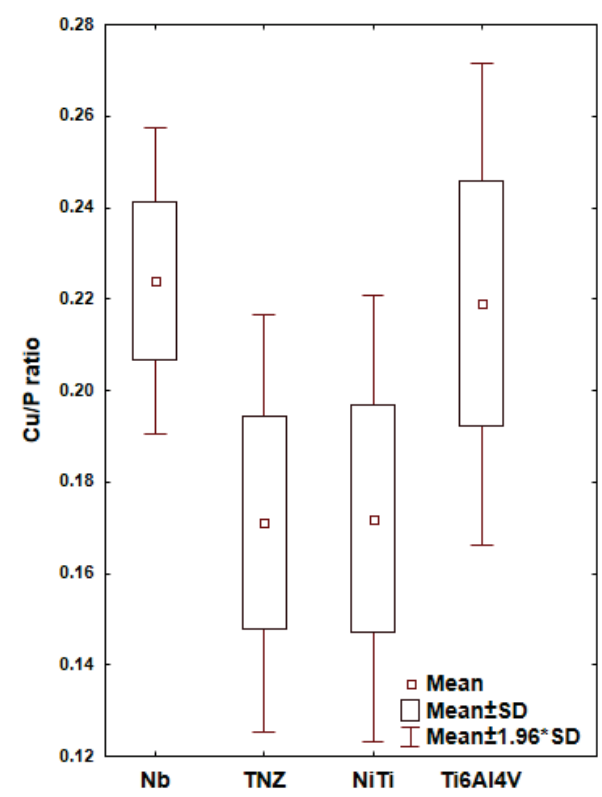

Figure 9 Box and whisker plots of the amount of copper-to-phosphorus ratios for $\mathrm{Nb}, \mathrm{TNZ}, \mathrm{NiTi}$ and Ti6Al4V in the surface coating formed after $\mathrm{PEO}$ at $450 \mathrm{~V}$ in the mixture containing $500 \mathrm{ml} \mathrm{H}_{3} \mathrm{PO}_{4}$ within 300 $\mathrm{g} \mathrm{Cu}\left(\mathrm{NO}_{3}\right)$

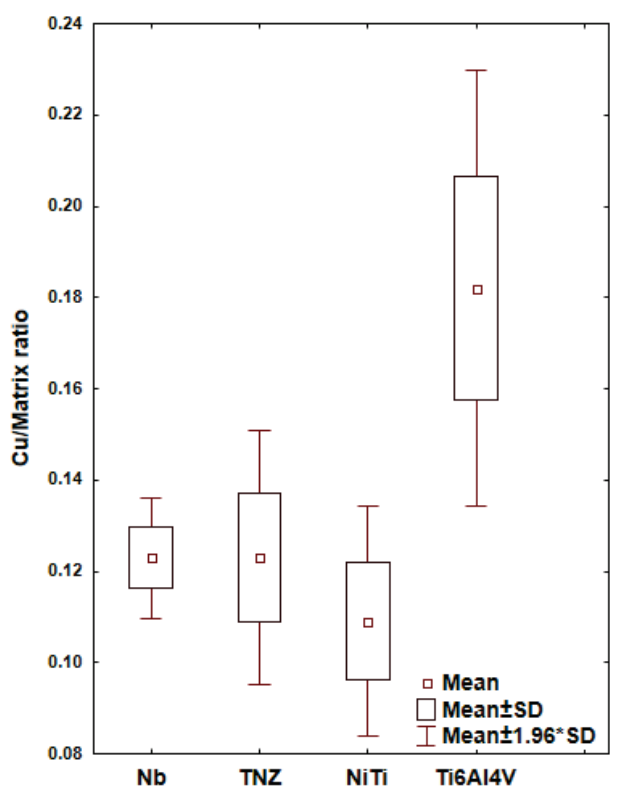

Figure 10 Box and whisker plots of the amount of copper-to-matrix ratios for $\mathrm{Nb}, \mathrm{TNZ}, \mathrm{NiTi}$ and $\mathrm{Ti} 6 \mathrm{Al} 4 \mathrm{~V}$ in the surface coating formed after $\mathrm{PEO}$ at $450 \mathrm{~V}$ in the mixture containing $500 \mathrm{ml} \mathrm{H}_{3} \mathrm{PO}_{4}$ within 300 $\mathrm{g} \mathrm{Cu}\left(\mathrm{NO}_{3}\right)$

In the significant t-test analyses of the amounts of copper-to-phosphorus, phosphorus-to-matrix and copper- to-matrix ratios (Figs. 9 through 11) of the studied biomaterials it was found that the $\mathrm{Cu} / \mathrm{P}$ data obtained may be classified with the same population. On the other hand, in the case of the significant t-test analysis of the amount of phosphorus-to-matrix ratio (Fig. 11), it should be noted that all of the analyzed data belong to different populations. The results presented in Fig. 10 also clearly indicate that only for pure Niobium and TNZ alloy the copper-to-matrix ratios can be considered as derived from the same population.

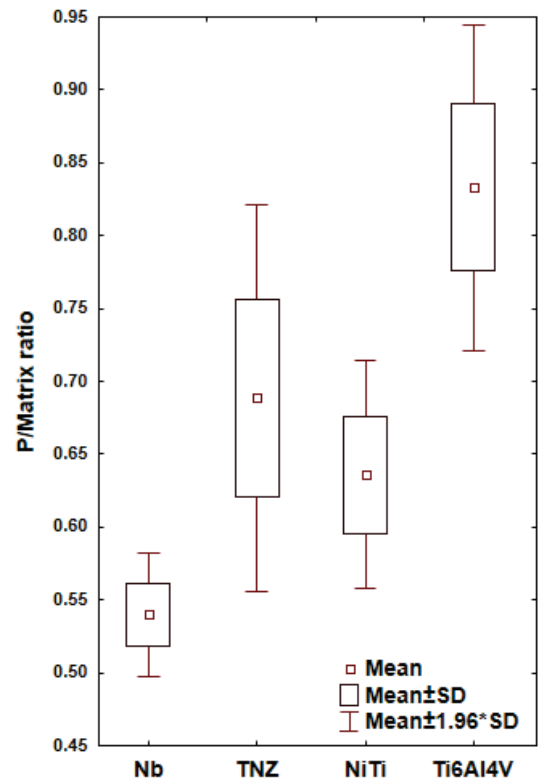

Figure 11 Box and whisker plots of the amount of phosphorous-tomatrix ratios for $\mathrm{Nb}$, TNZ, NiTi and Ti6Al4V in the surface coating formed after PEO at $450 \mathrm{~V}$ in the mixture containing of $500 \mathrm{ml} \mathrm{H}_{3} \mathrm{PO}_{4}$ within $300 \mathrm{~g} \mathrm{Cu}\left(\mathrm{NO}_{3}\right)$

\section{Discussion}

Titanium, niobium, zirconium and their alloys nowadays are very often used as biomaterial. It is due to their high biocompatibility, corrosion resistance and mechanical properties corresponding with and/or close to the human being bones and tissue. Concerning these features it is most interesting to create the coatings which are very different from the matrix in terms of mechanical properties, chemical composition and porosity. Moreover, it appears they can be created by electrochemical methods. In the present paper the Authors show the new way of formation of such coatings on niobium and titanium alloys using plasma electrolytic oxidation with a voltage of $450 \mathrm{~V}$ in new electrolytes composed of concentrated phosphoric acid with copper nitrate dissolved inside. Most important for biomaterials producers was to create a porous surface layer or coating consisting mainly of phosphates with some additional chemical elements placed and arranged in the whole volume of it (in our case, that chemical element is the bactericidal copper).

It is known that there are other methods in materials engineering, such as PVD or CVD techniques which can be used for creation of a thin layer of copper on the surface or creation of multi-layer structures with copper layers of varying thickness. But with such a method the characteristics of the copper ions release in function of 
time would be totally different than that achieved from the porous surface or coating. Proposed by the Authors, the approach using the plasma electrolytic oxidation as a method for treatment of the above-mentioned materials in electrolyte containing copper ions, allowed obtaining a uniform distribution of copper ions in the whole volume of coating. The greatest achievement is to adopt the standard set up for plasma electrolytic oxidation for modification of the coating only by changing the electrolyte. All our results show that the amount of copper that was obtained after 3 minutes of the treatment is relatively high (from 3 to $4 \mathrm{wt} \%$ ). To compare the coatings with different chemical compositions the Authors used three ratios, i.e. $\mathrm{Cu} / \mathrm{P}, \mathrm{Cu} / \mathrm{Matrix}$ and $\mathrm{P} /$ Matrix. The $\mathrm{Cu} / \mathrm{P}$ ratio may indicate the proportion between copper and phosphorus, which comes mainly from electrolyte. The $\mathrm{Cu} / \mathrm{Matrix}$ and $\mathrm{P} / \mathrm{Matrix}$ ratios show the relative amount of copper and phosphorus incorporated by the formed coatings with the relation to matrix. On the other hand, the $\mathrm{Cu} / \mathrm{P}$ ratio may be considered as an error-free coefficient that the $\mathrm{Cu} / \mathrm{Matrix}$ and P/Matrix may show, where the error is connected with the detection of signals coming from the substrate (matrix). However, after analyzing all these three ratios it appears there is no problem with the correct interpretation of the obtained results. In order to present the results to the reader, they are displayed consecutively as mean, standard deviation, median and range.

On the basis of the EDX data of coating formed after the plasma electrolytic oxidation on niobium the $\mathrm{Cu} / \mathrm{P}$ ratio was determined and equaling to $0,22 \pm 0,02$ (median: 0,23 , range: 0,05 ). These results mean that in the coating there is over 4,5 times by weight more phosphorus than copper. A similar value of $\mathrm{Cu} / \mathrm{P}$ ratio was obtained for Ti6Al4V after PEO, and it equals to $0,22 \pm 0,03$ (median: 0,22 , range: 0,08 ), that has been confirmed by the significant t-tests [41]. Inside the coatings formed on TNZ and NiTi alloys there was about six times more phosphorus than copper (by weight). Such results are obvious, because phosphates are the main component of coatings. The point is that the coatings formed on TNZ and NiTi may be classified to different populations than those created on $\mathrm{Nb}$ and Ti6Al4V [41]. The $\mathrm{Cu} / \mathrm{P}$ ratios for coatings on TNZ and $\mathrm{NiTi}$ equal to $0,17 \pm 0,02$ (median: 0,17 , range: 0,07 ) and $0,17 \pm 0,02$ (median: 0,18, range: 0,08 ), respectively. The $\mathrm{Cu} / \mathrm{Matrix}$ and $\mathrm{P} / \mathrm{Matrix}$ ratios show the amount of copper and phosphorus with respect to the substrate elements.

Based on the P/Matrix data, it is possible to find that the highest amount of phosphorus was recorded in the coating formed on Ti6Al4V (P/Matrix $=0,83 \pm 0,06$, median: 0,81 , range: 0,19$)$, whereas the least one was found for pure niobium ( $\mathrm{P} /$ Matrix $=0,54 \pm 0,02$, median: $0,55$, range: 0,06$)$. Assuming that it depends mainly on the coating thickness, it can be stated that the coating formed on niobium is thinner than that one formed on Ti6Al4V alloy. The coatings formed on TNZ (P/Matrix $=0,69 \pm 0,07$, median: 0,69, range: 0,22) and $\mathrm{NiTi}$ (P/Matrix $=0,64 \pm 0,04$, median: 0.62, range: 0.11 ) have their thicknesses between those on niobium and Ti6Al4V alloy. In case of $\mathrm{Cu} /$ Matrix ratio, the highest value was noted for Ti6Al4V alloy $(\mathrm{Cu} /$ Matrix $=0,18 \pm 0,02$, median: 0,18 , range: 0,07$)$ and the lowest for the others, i.e. NiTi $(0.11 \pm 0.01$, median:0.11, range:0.04), TNZ $(0.12 \pm 0.01$, median: 0.13 , range: 0.05$)$, $\mathrm{Nb}(0.12 \pm 0.01$, median:0.12, range: 0.02$)$. This would mean that the coating formed on Ti6Al4V alloy during PEO is the thickest one.

The PEO process proposed in this study for metallic biomaterials appears to be of high value for increasing biocompatibility of specific devices. Its novelty with the presented results prompted us to further continue investigations, specifically including Glow Discharge Optical Emission Spectroscopy (GDOES) measurements and X-ray Photoelectron Spectroscopy (XPS) studies [42]. They are to confirm our findings given in this paper.

\section{Conclusions}

The following conclusions may be formulated after the studies:

- $\quad$ after the Plasma Electrolytic Oxidation (PEO) of pure niobium and titanium alloys at the voltage of $450 \mathrm{~V}$ in concentrated $\mathrm{H}_{3} \mathrm{PO}_{4}$ within $\mathrm{Cu}\left(\mathrm{NO}_{3}\right)_{2}$ the obtained surface coatings are porous

- it is possible to incorporate the copper ions into the pure niobium and titanium alloys at the voltage of $450 \mathrm{~V}$ in concentrated $\mathrm{H}_{3} \mathrm{PO}_{4}$ within $\mathrm{Cu}\left(\mathrm{NO}_{3}\right)_{2}$

- $\mathrm{Cu} / \mathrm{P}$ and $\mathrm{P} /$ Matrix ratios were calculated for all studied biomaterials.

Moreover, some additional conclusions may be drawn:

- inside the surface coatings formed on $\mathrm{Nb}$ and on Ti6Al4V alloy there is over 4,5 times more phosphorus than copper (by weight)

- $\quad$ inside the surface coatings formed on TNZ and NiTi alloys there is about six times more phosphorus than copper (by weight)

- it appears the PEO coating formed on Ti6Al4V is thicker and more copper-enriched than that one formed on the pure Niobium

- the studies show the PEO coating formed on TNZ is thicker and more copper-enriched than that one formed on NiTi

- on the basis of the significant t-test results it can be concluded that the $\mathrm{Cu} / \mathrm{P}$ data obtained from the analysis of surface coatings of pure Niobium and Ti6Al4V alloy may be classified to the same population

- on the basis of the significant t-test results it can be concluded that the P/Matrix data obtained from all the studied surfaces should be classified to different populations

- on the basis of the significant t-test results it can be concluded that the $\mathrm{Cu} /$ Matrix data obtained from the analyses of the surface coatings of pure Niobium and TNZ alloy may be classified to the same population [41].

\section{Acknowledgements}

Prof. Dr.-Ing. Winfried Malorny and Dr. Torsten Barfels from Hochschule Wismar (Germany) are highly acknowledged for making access to the SEM/EDX apparatus to perform the studies. Dr. Hugo Ricardo 
Zschommler Sandim, Associate Professor of Departamento de Engenharia de Materiais, Universidade de Saõ Paulo (Brazil) is thankful for sending the niobium samples for studies. Dra Gemma Vara and Dra M. Belén García-Blanco from Fundación Cidetec, Parque Tecnológico de San Sebastián $\mathrm{P}^{\circ}$ Miramón, 19620009 Donostia-San Sebastián (Gipuzkoa)(Spain) are highly acknowledged for delivering Ti6Al4V material for the PEO experiments. Professor Frédéric Prima from Ecole Nationale Supérieure de Chimie de Paris (France) is thankful for sending TNZ alloy samples to use for the studies.

\section{References}

[1] Hryniewicz, T.; Rokicki, R.; Rokosz, K. Corrosion and surface characterization of titanium biomaterial after magnetoelectropolishing. // Surface \& Coatings Technology. 203, 10-11(2009), pp. 1508-1515. DOI: 10.1016/j.surfcoat.2008.11.028

[2] Hryniewicz, T.; Rokosz, K.; Valiček, J.; Rokicki, R. Effect of magnetoelectropolishing on nanohardness and Young's modulus of titanium biomaterial. // Materials Letters. 83, (2012), pp. 69-72. DOI: 10.1016/j.matlet.2012.06.010

[3] Sowa, M.; Kazek-Kesik, A.; Krzakala, A.; Socha, R. P.; Dercz, G.; Michalska, J.; Simka, W. Modification of niobium surfaces using plasma electrolytic oxidation in silicate solutions. // Journal of Solid State Electrochemistry. 18, 11(2014), pp. 3129-3142. DOI: 10.1007/s10008-013-23417

[4] Hryniewicz, T.; Rokosz, K.; Zschommler, S. H. R. SEM/EDX and XPS studies of niobium after electropolishing. // Applied Surface Science. 263, (2012), pp. 357-361. DOI: 10.1016/j.apsusc.2012.09.060

[5] Sowa, M.; Kazek-Kęsik, A.; Socha, R. P.; Dercz, G.; Michalska, J.; Simka, W. Modification of tantalum surface via plasma electrolytic oxidation in silicate solutions. // Electrochimica Acta, 114, (2013), pp. 627-636. DOI: 10.1016/j.electacta.2013.10.047

[6] Simka, W.; Sowa, M.; Socha, R. P.; Maciej, A.; Michalska, J. Anodic oxidation of zirconium in silicate solutions. // Electrochimica Acta, 104, (2013), pp. 518-525. DOI: 10.1016/j.electacta.2012.10.130

[7] Sowa, M.; Piotrowska, M.; Widziołek, M.; Dercz, G.; Tylko, G.; Gorewoda, T.; Osyczka, A. M.; Simka, W. Bioactivity of coatings formed on Ti-13Nb-13Zr alloy using plasma electrolytic oxidation. Materials Science \& Engineering C - Materials for Biological Applications. 49, (2015), pp. 159-173. DOI: 10.1016/j.msec.2014.12.073

[8] Hryniewicz, T.; Rokosz, K.; Rokicki, R.; Prima, F. Nanoindentation and XPS Studies of Titanium TNZ Alloy after Electrochemical Polishing in a Magnetic Field. // Materials. 8, 1(2015), pp. 205-215. DOI: 10.3390/ma8010205

[9] Rokicki, R.; Hryniewicz, T.; Pulletikurthi, C.; Rokosz, K.; Munroe, N. Towards a Better Corrosion Resistance and Biocompatibility Improvement of Nitinol Medical Devices. // Journal of Materials Engineering and Performance. 24, 4(2015), pp. 1634-1640. DOI: 10.1007/s11665-015-1429-x

[10] Simka, W.; Socha, R. P.; Dercza, G.; Michalska, J.; Maciej, A.; Krzakala, A. Anodic oxidation of Ti-13Nb-13Zr alloy in silicate solutions. // Applied Surface Science. 279, (2013), pp. 317-323. DOI: 10.1016/j.apsusc.2013.04.091

[11] Hryniewicz, T.; Rokosz, K.; Rokicki, R.; Prima, F. Nanoindentation Studies of TNZ and Ti2448 Biomaterials after Magnetoelectropolishing. // Advances in Materials Science. 14 3, 41(2014), pp. 34-44. DOI: 10.2478/adms-20140014
[12] Rokosz, K.; Hryniewicz, T.; Raaen, S. Development of plasma electrolytic oxidation for improved Ti6A14V biomaterial surface properties. // The International Journal of Advanced Manufacturing Technology. 85, 9(2016), pp. 2425-2437. DOI: 10.1007/s00170-015-8086-y

[13] Rokosz, K.; Lahtinen, J.; Hryniewicz, T.; Rzadkiewicz, S. XPS depth profiling analysis of passive surface layers formed on austenitic AISI 304L and 316L SS after HighCurrent-Density Electropolishing. Surface and Coatings Technology. 276, (2015), pp. 516-520. DOI: 10.1016/j.surfcoat.2015.06.022

[14] Rokosz, K. Electrochemical Polishing of Steels in a Magnetic Field (Polerowanie elektrochemiczne stali w polu magnetycznym), Monograph No. 219, Copyright by Koszalin University of Technology, Koszalin, 2012 (211 pages).

[15] Hryniewicz, T.; Konarski, P.; Rokosz, K.; Rokicki, R. SIMS analysis of hydrogen content in near surface layers of AISI 316L SS after electrolytic polishing under different conditions. // Surface and Coatings Technology. 205, 1718(2011), pp. 4228-4236. DOI: 10.1016/j.surfcoat.2011.03.024

[16] Rokosz, K.; Hryniewicz, T.; Raaen, S.; Valiček, J. SEM/EDX, XPS, corrosion and surface roughness characterization of AISI 316L SS after electrochemical treatment in concentrated HNO3. // Tehnicki VjesnikTechnical Gazette. 22, 1(2015), pp. 125-131. DOl: 10.17559/TV-20140211130812

[17] Rokosz, K.; Simon, F.; Hryniewicz, T.; Rzadkiewicz, S. Comparative analysis of passive layers composition on AISI $304 \mathrm{~L}$ SS after standard and high-current density electropolishing. // Surface and Interface Analysis. 47, 1(2015), pp. 87-92. DOI: 10.1002/sia.5676

[18] Rokosz, K.; Hryniewicz, T. XPS measurements of LDX 2101 duplex steel surface after magnetoelectropolishing. // International Journal of Materials Research. 104, 12(2013), pp. 1223-1232. DOI: $10.3139 / 146.110984$

[19] Hryniewicz, T.; Rokosz, K. Investigation of selected surface properties of AISI $316 \mathrm{~L}$ SS after magnetoelectropolishing. // Materials Chemistry and Physics. 123, 1(2010), pp. 47-55. DOl: 10.1016/j.matchemphys.2010.03.060

[20] Hryniewicz, T.; Rokosz, K. Polarization Characteristics of Magnetoelectropolishing Stainless Steels. // Materials Chemistry and Physics. 122, 1(2010), pp. 169-174. DOl: 10.1016/j.matchemphys.2010.02.055

[21] Rokosz, K.; Hryniewicz, T.; Raaen, S. Characterization of passive film formed on AISI 316L Stainless Steel after Magnetoelectropolishing in a Broad Range of Polarization Parameters. // Steel Research International. 83, 9(2012), 910-918. DOI: 10.1002/srin.201200046

[22] Rokosz, K.; Hryniewicz, T.; Raaen, S. Cr/Fe ratio by XPS spectra of magnetoelectropolished AISI 316L SS fitted by Gaussian-Lorentzian shape lines. // Tehnicki VjesnikTechnical Gazette. 21, 4(2014), pp. 533-538.

[23] Rokosz, K.; Simon, F.; Hryniewicz, T.; Rzadkiewicz, S. XPS study of surface layer formed on AISI 316L after High-Current Density Electropolishing. // Solid State Phenomena. 227, (2015), pp. 155-158. DOI: 10.4028/www.scientific.net/SSP.227.167

[24] Rokosz, K.; Hryniewicz, T.; Lukeš, J.; Šepitka, J. Nanoindentation studies and modeling of surface layers on austenitic stainless steels by extreme electrochemical treatments, Surface and Interface Analysis. 47, 6(2015), pp. 643-647. DOI: 10.1002/sia.5758

[25] Rokosz, K.; Hryniewicz, T.; Rzadkiewicz, S.; Raaen, S. High-Current Density Electropolishing (HDEP) of AISI 316L SS (EN 1.4404) Stainless Steel. // Tehnicki VjesnikTechnical Gazette. 22, 2(2015), pp. 415-424. DOl: 10.17559/TV-20140722110711 
[26] Hryniewicz, T.; Rokosz, K. Corrosion resistance of magnetoelectropolished AISI 316L SS biomaterial. // AntiCorrosion Methods and Materials. 61, 2(2014), pp. 57-64. DOI: 10.1108/ACMM-03-2013-1249

[27] Rokicki, R.; Hryniewicz, T. Enhanced oxidation-dissolution theory of electropolishing. // Transactions Inst. Met. Finish. 90, 4(2012), $\quad$ pp. 188-196. DOI: 10.1179/0020296712Z.00000000031

[28] Hryniewicz, T.; Rokosz, K. Highlights of magnetoelectropolishing. // Frontiers in Materials: Corrosion Research. 1, 3(2014), pp. 1-7. DOI: 10.3389/fmats.2014.00003

[29] Hryniewicz, T.; Rokosz, K.; Rokicki, R. Magnetic Fields for Electropolishing Improvement: Materials and Systems. // International Letters of Chemistry, Physics and Astronomy. 4, (2014), pp. 98-108. http://www.ilcpa.pl/wpcontent/uploads/2013/10/ILCPA-4-2014-98-1081.pdf

[30] Rokicki, R.; Haider, W.; Hryniewicz, T. Influence of Sodium Hypochlorite Treatment of Electropolished and Magnetoelectropolished Nitinol Surfaces on Adhesion and Proliferation of MC3T3 Pre-osteoblast Cells. // Journal of Materials Science: Materials in Medicine. 23, (2012), pp. 2127-2139. DOI: 10.1007/s10856-012-4696-1

[31] http://www.materion-gmbh.de/en/Surface.html

[32] Jelinek, M.; Kocourek, T.; Remsa, J.; Weiserová, M.; Jurek, K.; Mikšovský, J.; Strnad, J.; Galandáková, A.; Ulrichová, J. Antibacterial, cytotoxicity and physical properties of laser - Silver doped hydroxyapatite layers. // Materials Science and Engineering: C. 33, 3(2013), pp. 1242-1246. DOI: 10.1016/j.msec.2012.12.018

[33] Mishra, G.; Dash, B.; Pandey, S.; Mohanty, P. P. Antibacterial actions of silver nanoparticles incorporated $\mathrm{Zn}-\mathrm{Al}$ layered double hydroxide and its spinel. // Journal of Environmental Chemical Engineering. 1, 4(2013), pp. 1124-1130. DOI: 10.1016/j.jece.2013.08.031

[34] Rajendran, A.; Pattanayak, D. K. Silver incorporated antibacterial, cell compatible and bioactive titania layer on Ti metal for biomedical applications. RSC Advances. // 106, 4(2014), pp. 61444-61455. DOI: 10.1039/C4RA13107J

[35] Trujillo, N. A.; Oldinski, R. A.; Ma, H., Bryers, J. D.; Williams, J. D.; Popat, K. C. Antibacterial effects of silverdoped hydroxyapatite thin films sputter deposited on titanium. // Materials Science and Engineering: C. 32, 8(2012), pp. 2135-2144. DOI: 10.1016/j.msec.2012.05.012

[36] Xiangyu Zhang; Xiaobo Huang; Yong Ma; Naiming Lin; Ailan Fan; Bin Tang. Bactericidal behavior of $\mathrm{Cu}$ containing stainless steel surfaces. // Applied Surface Science. 258, (2012), pp. 10058-10063. DOI: 10.1016/j.apsusc.2012.06.074

[37] Xiaohong Yao; Xiangyu Zhang; Haibo Wu; Linhai Tian; Yong $\mathrm{Ma}$; Bin Tang, Microstructure and antibacterial properties of $\mathrm{Cu}$-doped $\mathrm{TiO} 2$ coating on titanium by microarc oxidation. // Applied Surface Science. 292, (2014), pp. 944-947. DOI: 10.1016/j.apsusc.2013.12.083

[38] Hempel, F.; Finke, B.; Zietz, C.; Bader, R.; Weltmann, K.D.; Polak, M. Antimicrobial surface modification of titanium substrates by means of plasma immersion ion implantation and deposition of copper. // Surface \& Coatings Technology. 256, (2014), pp. 52-58. DOI: 10.1016/j.surfcoat.2014.01.027

[39] StatSoft, Inc. (2011). STATISTICA (data analysis software system), version 10. www.statsoft.com

[40] Kusnerova, M.; Valiček, J.; Harničarova, M.; Hryniewicz, T.; Rokosz, K.; Palkova, Z.; Vaclavik, V.; Repka, M.; Bendova, M. A Proposal for Simplifying the Method of Evaluation of Uncertainties in Measurement Results. // Measurement Science Review. 13, 1(2013), pp. 1-6. DOI: 10.2478/msr-2013-0007
[41] Kukiełka, L. Fundamentals of Engineering Studies (in Polish), Sci. Ed. by PWN, Warsaw, 2002, ISBN 8301137495, 9788301137496, 273 pages

[42] Rokosz, K.; Hryniewicz, T.; Raaen, S.; Chapon, P.; Dudek, Ł. GDOES and XPS with SEM and EDS analysis of coatings obtained on Titanium after Plasma Electrolytic Oxidation in the orthophosphoric acid with copper nitrate electrolyte. // Surface and Interface Analysis. 49, 4(2017), pp. 3030-315. DOI: 10.1002/sia.6136

\section{Authors' addresses}

Krzysztof Rokosz, DSc PhD, Assoc. Prof Division of Surface Electrochemistry and Technology, Koszalin University of Technology, Racławicka 15-17, 75-620 Koszalin, Poland E-mail: rokosz@tu.koszalin.pl

\section{Tadeusz Hryniewicz, DSc PhD ME CE, Professor} (Corresponding author)

Division of Surface Electrochemistry and Technology, Koszalin University of Technology, Racławicka 15-17, PL 75-620 Koszalin, Poland E-mail: Tadeusz.Hryniewicz@tu.koszalin.pl 